\title{
University Internationalization and University Autonomy
}

\section{Toward a Theoretical Understanding}

Turcan, Romeo V.; Gulieva, Valeria

Published in:

(Re)Discovering University Autonomy

DOI (link to publication from Publisher):

10.1057/9781137388728_15

Publication date:

2016

\section{Document Version}

Early version, also known as pre-print

Link to publication from Aalborg University

Citation for published version (APA):

Turcan, R. V., \& Gulieva, V. (2016). University Internationalization and University Autonomy: Toward a

Theoretical Understanding. In R. V. Turcan, J. Reilly, \& L. Bugaian (Eds.), (Re)Discovering University Autonomy: The Global Market Paradox of Stakeholder and Educational Values in Higher Education (pp. 215-235). Palgrave Macmillan. https://doi.org/10.1057/9781137388728_15

\section{General rights}

Copyright and moral rights for the publications made accessible in the public portal are retained by the authors and/or other copyright owners and it is a condition of accessing publications that users recognise and abide by the legal requirements associated with these rights.

- Users may download and print one copy of any publication from the public portal for the purpose of private study or research.

- You may not further distribute the material or use it for any profit-making activity or commercial gain

- You may freely distribute the URL identifying the publication in the public portal -

\section{Take down policy}

If you believe that this document breaches copyright please contact us at vbn@aub.aau.dk providing details, and we will remove access to the work immediately and investigate your claim. 


\title{
CHAPTER 15
}

\section{University Internationalization and University Autonomy: Toward a Theoretical Understanding}

\author{
Romeo V. Turcan and Valeria Gulieva
}

\section{Introduction}

The aim of this chapter is to deepen our theoretical understanding of the internationalization of universities. Specifically, we explore the relationship between university internationalization and university autonomy, and argue that the process of university internationalization and its sustainability is dependent on domestic and international university autonomy settings. We conjecture that the process of university internationalization and its sustainability are determined by the structure and exercise of university autonomy settings at home and in the host (target) countries, and that the process itself cannot be successfully achieved and maintained without changes in the autonomy settings.

At the outset of the chapter, it is important to define its scope. University internationalization at the micro-level, such as the arrangement of student and staff mobility, engagement of the academic staff in university internationalization, internationalization of the curriculum, development of a global mind-set, establishment of academic partnerships with foreign universities, and participation in global university networks and consortia (Bartell 2003, Friesen 2012, Horta 2009, Jiang and Carpenter 2013, Pfotenhauer et al. 2013, Urbanovič and Wilkins 2014), is outside the scope of our chapter. Although it is our view that engagement in "partnerships," "networks," and "consortia" has an impact on the exercise and understanding of autonomy, the chapter focuses on advanced-high-risk, high-commitment, and high-cost-internationalization (nonequity or equity) modes, such as branch campuses, franchised academic programs or degrees, or greenfield investments as independent institutions based on foreign academic models (Altbach and Knight 2007). We also limit the scope of our chapter to the internationalization of universities from developed to developing countries. 
The chapter addresses a number of current issues and concerns, as well as gaps at the intersection of university internationalization and university autonomy. Advanced internationalization has become an accepted practice: as of today, there are approximately 200 international, degree-awarding branch campuses worldwide (GHE 2014). Such aspirations toward advanced internationalization are not without pitfalls, however. Conventional internationalization wisdom suggests that universities should adapt their strategies, resources, structures, and organizations to international environments (Edwards and Edwards 2001), and adapt to and comply with host country university autonomy (Bartell 2003, Knight 2012). The challenge in pursuing this "wisdom," however, is to address to what degree universities, in embracing new, dissimilar, and sometimes conflicting dimensions of the financial, legal, organizational, staffing, and academic autonomy of the host country, are compromising key aspects of their own autonomy and core mission. This mismatch in institutional autonomy settings may lead to the de-internationalization of universities. Recent examples of university withdrawal from international markets can be found in vignette 15.1 .

\section{Vignette 15.1: Recent evidence of university de-internationalization}

Within the last decade, at least 11 branch campuses created by well-resourced institutions have closed (GHE 2014). Some others decided against establishing a branch campus abroad. To name the most prominent cases, George Mason University, the University of Waterloo, Michigan State University, and the University of Southern Queensland closed their campuses in the United Arab Emirates (UAE); the University of New South Wales (UNSW) closed its campus in Singapore, and New York University announced withdrawal of its campus there for 2014; Bond University (Australia) and De Montfort University (United Kingdom) withdrew from South Africa; and the Royal Melbourne Institute of Technology exited from Malaysia (Altbach 2011, GHE 2014, ICEF Monitor 2013, Ng and Tan 2010, Olds 2009, Sidhu 2009, Bennett and Kane 2009, Altbach and Knight 2007).

In 2005, after a long evaluation process and a series of debates, the United Kingdom's Warwick University decided against proceeding with its plans to establish a branch campus in Singapore and declined a generous offer made by the local government (OBHE 2007c). After an eight-month feasibility study was undertaken, in addition to issues of financial risks and legal responsibilities, Warwick University raised concerns over the state of human rights and academic freedom in Singapore. According to Burton (2005), "Singapore requires international educational institutions operating in the city-state to agree not to conduct activities seen as interference in domestic affairs." Despite the relatively positive financial forecast for the project, the academic community at Warwick University appeared to be against establishing a branch campus.

The University of New South Wales closed its branch campus in Singapore, which was considerably supported by the local government, after only four months of operation (OBHE 2007a). The unexpected closure was largely explained by weak enrollment projections, which reportedly made the institution financially 